Article

\title{
The Spitzenkandidaten in the European Parliament Election Campaign Coverage 2014 in Germany, France, and the United Kingdom
}

\author{
Heidi Schulze \\ Department for Communication Research, Dresden University of Technology, 01069 Dresden, Germany; \\ E-Mail: heidi.schulze@tu-dresden.de
}

Submitted: 30 September 2015 | Accepted: 18 January 2016 | Published: 29 February 2016

\begin{abstract}
Elections to the European Parliament are characterised by a steady decline in voter turnout. To tackle this problem, in 2014, several groups of the European Parliament nominated pan-European Spitzenkandidaten who were expected to personalise the elections and mobilise European voters. Based on this development, this study analyses the media coverage of the 2014 EP elections with special focus on the role of the Spitzenkandidaten. A quantitative content analysis of European election campaign coverage in the opinion leading newspapers of three influential EU member states, Germany, France, and the United Kingdom was carried out. The results show large candidate- and country-specific differences regarding the visibility and thematic coverage of the EP elections in general as well as the presentation of the Spitzenkandidaten. The Spitzenkandidaten were not very visible in either the German, French, or British newspaper coverage. With respect to the presence and media personalisation of the Spitzenkandidaten, the newspaper coverage of the EP election does not demonstrate any mobilising effect and thus does not reflect the high expectations the European Parliament attributed to the nomination of the Spitzenkandidaten.
\end{abstract}

\section{Keywords}

comparative cross-national analysis; content analysis; European elections; media coverage; media personalisation; Spitzenkandidaten

\section{Issue}

This article is part of the issue "How Different Were the European Elections of 2014?", edited by Wouter van der Brug, Katjana Gattermann and Claes de Vreese (University of Amsterdam, The Netherlands).

(C) 2016 by the author; licensee Cogitatio (Lisbon, Portugal). This article is licensed under a Creative Commons Attribution 4.0 International License (CC BY).

\section{Introduction}

This time it's different. With this slogan the European Parliament launched the campaign for the 2014 elections to the European Parliament (EP) to announce that they expected these elections to differ substantially from previous ones (Chaucheprat, 2014). They were the first EP elections since the Lisbon Treaty, which strengthened the position of the EP, had come into effect. For example, it was assigned the task of electing the President of the European Commission. Although the President was still officially to be nominated by the European Council, the five largest EP groups used this reform to each nominate their preferred candidate for the position: Jean-Claude Juncker, former prime minister of Luxembourg and chairman of the Eurogroup (EPP); Martin Schulz, president of the EP since 2012 (S\&D); Guy Verhofstadt, former prime minister of Belgium, member of the EP and leader of the ALDE faction (ALDE); Ska Keller, member of the EP since 2009 (Greens/EFA), and Alexis Tsipras, vice-president of the European Left and prime minister of Greece since 2015 (GUE/NGL). The aim of the introduction of the pan-European Spitzenkandidaten was to personalise the election and ultimately mobilise the European electorate (Niedermayer, 2014, p. 523). This structural innovation was a concerted effort to address the steady decline in voter turnout since the first European elections in 1979. 
Empirical findings indeed confirm that the personalisation of an election campaign can have a positive impact on the overall election process: candidates as intermediaries of complex policy issues can reduce this complexity by rendering politics more accessible, and thus, not only inform but ultimately mobilise voters (Brettschneider, 2002; Huss, 2007; Lass, 1995). Personalisation increases personal involvement by facilitating voters' comprehension of political issues (Bentele \& Fähnrich, 2010; Merkle, 2015; Ohr, 2000) and was found to have an overall positive effect on attitudes towards politics (Jebril, Albaek, \& de Vreese, 2013).

Subsequent to their nomination, each Spitzenkandidat launched a pan-European election campaign in order to introduce him-/herself to the European public and to present the position of his/her political group. However, the candidates' campaign budgets were relatively low and they tended to focus their campaigning efforts on Central European countries (Pop, 2014). Schulz, for instance, visited Germany eleven times and Juncker went to Germany eight times. France and Belgium received more attention than other European countries too, while the United Kingdom for instance did not appear on the campaign route of either of these two previously mentioned candidates at all (Schmitt, Hobolt, \& Popa, 2014). With regards to timing, the candidates focused their campaign activities on the last three to four weeks before the elections, resulting in an intensified effort during May, the month of the ballot. Furthermore, the Spitzenkandidaten exchanged their viewpoints in the context of several European TV debates, a novelty in the context of EP elections. From April 9 to May 20, nine TV debates were held in the three working languages of the EU (French, English and German). They were broadcast in all member states on national television and online via several web outlets. The majority of the debates, however, focused exclusively on the candidates of the two largest EP factions, Juncker and Schulz. In addition to regular campaigning the candidates used online social networks such as Facebook and Twitter in which Schulz again showed the highest campaign activity. As a result, he garnered the most attention in terms of followers and likes (Pop, 2014; Schmitt et al., 2014).

However, there is no consensus with regards to the extent that the new approach can be evaluated as a success, if at all. The presence of Spitzenkandidaten supported the professionalisation process of EP elections in general, but, in terms of the final voter turnout, the alterations in the electoral process did not have the effect the EP factions desired, and instead they reached a new low point. Still, compared to previous EP elections, the turnout decreased to a lesser extent and preliminary research demonstrates that knowledge of the candidates had a minor positive influence on voter turnout (Schmitt, Hobolt, \& Popa, 2015). It is not enough, however, to focus on only one of the groups of actors involved in the electoral process, the voters. Since the spatial distance of candidates and voters is much higher in the context of EP elections than during national elections, the intermediary role of the mass media is of crucial importance. Although the Spitzenkandidaten had held important European political positions prior to the elections, they were mostly unknown outside their home countries (Hobolt, 2014; Marino, 2014; Piedrafita \& Renman, 2014). Consequently, with respect to the low voter turnout the question arises as to how far the EP elections were covered in general and to what extent the media referred to the Spitzenkandidaten in their election campaign coverage. Previous studies have confirmed large-scale country-specific differences with respect to the coverage of the EP elections. It is necessary, therefore, to deploy a cross-national comparative approach in order to analyse the question of media coverage of the Spitzenkandidaten. This study analyses the three largest countries in the European Union, Germany, France, and the United Kingdom. These three countries are well suited for comparison in the context of EP elections not only because of their population size and, thus, their number of seats and influence in the EP, but also because they differ in terms of their media system, with each country reflecting one of three different media systems according to Hallin and Mancini (2004). Additionally, in contrast to general voter turnout, voter participation in these three countries increased relative to the 2009 EP elections, despite differences in campaign efforts.

\section{The EP Elections in the Media}

Due to the physical and conceptual distance between the European institutions, their politicians and voters, mass media functions as a key actor and as a decisive factor in the information and opinion-forming processes of voters in the context of EP elections (Strömbäck et al., 2013). The mass media is the main source of information for the electorate, even more so during national elections. Various studies have confirmed that greater visibility of the EP elections in the media positively influences the factual knowledge and turnout of the EP elections (Banducci \& Semetko, 2003; de Vreese \& Boomgaarden, 2006; Gerstlé, Magni-Berton, \& Piar, 2006; Hobolt, Spoon, \& Tilley, 2009; Weßels, 2005). However, compared to national elections, the mass media covers the EP elections less extensively and tends to focus its campaign coverage on the very last days of the campaign (Boomgaarden, Vliegenthart, de Vreese, \& Schuck, 2010; Leroy \& Siune, 1994; Peter, 2004). Still, cross-national comparisons of different EP elections found a general increase of their visibility over time (Boomgaarden et al., 2010; de Vreese, Banducci, Semetko, \& Boomgaarden, 2006; Schuck, Azrout et al., 2011; Vliegenthart, Schuck, Boomgaarden, \& de Vreese, 2008). In terms of media-related differences, several studies concluded that quality newspapers not only report more frequently but also 
more comprehensively on the EP elections than tabloid media, which rarely cover the elections at all (Boomgaarden et al., 2013; Brettschneider \& Rettich, 2005; Maier \& Maier, 2008).

Regarding the coverage in the countries Germany, France, and the United Kingdom, cross-national comparative studies have found apparent country-specific differences, though they seldom discuss these differences in detail. According to Schuck, Azrout et al. (2011) the 2009 EP elections were comparatively most visible in French newspaper coverage, less so in the British media, and least of all in Germany; these differences were only minimal, though. However, their findings contrast those of Strömbäck et al. (2011) who found the EP elections to be far more visible in the German coverage than in the British. These contrary results might be a consequence of a difference in research design: Schuck, Azrout et al. (2011) only analysed the front page of the newspapers while Strömbäck et al. (2011) considered the whole newspaper for their analysis. As for the thematic coverage of the EP elections, British newspapers covered the EP elections predominantly from a Eurosceptic and national perspective (Bruter \& Harrison, 2007; Negrine, 2006; Semetko, Blumler, Gurevitch, \& Weaver, 1991). Similarly, the German coverage focuses mostly on the national aspects of the topics related to EP elections (Adam, 2007; Lozac'h, 2007; Tenscher, 2006; Voltmer \& Eilders, 2003; Wilke \& Reinemann, 2005). Results concerning the content of the French media coverage of EP elections are scarce but in general, several studies agree that in all three countries the EP elections are far less visible in the media coverage than national elections (Adam, 2007; Brettschneider \& Rettich, 2005; Gerstlé et al., 2006; Odmalm, 2005, 2006).

Recent findings suggest that media attention, and thus public attention towards the EU, increased prior to the EP elections due to the economic crisis in the Euro area (Kriesi \& Grande, 2014 in Hobolt, 2014). At the time of the EP election campaign the European debt crisis was one of the most salient topics and was perceived as a European issue (Cassel \& Thomas, 2014; Hobolt, 2014). Additionally, Negrine (2006) argues that the professionalisation of the EP election campaign could influence the coverage positively. The nomination of Spitzenkandidaten and their subsequent campaigning contributed to the professionalisation process of EP elections, as they have done in national elections. However, it remains unclear how much this nomination affected the media coverage of the EP election campaign in general. In order to understand and evaluate the role of the Spitzenkandidaten, it is essential to consider the context in which they are discussed and thus focus on the entire coverage of the EP elections. Consequently, the question arises of how the EP election campaign was covered in the national media in France, Germany, and the United Kingdom (RQ1). The above review of similar studies demonstrates that the majority of contributions analysing the EP election campaign coverage focuses on the variables 'visibility of the campaign', 'main topics', and 'perspective of the coverage'. Thus, these three aspects are of special interest in the context of the general description of the 2014 EP election campaign.

\section{Media Personalisation in France, Germany, and the United Kingdom}

Definitions and operationalisations of the multifaceted construct personalisation vary enormously (Adam \& Maier, 2010). In a very broad sense, personalisation describes an increasing focus on individual senior politicians. In the context of election campaigns, personalisation concerns three different dimensions: campaigning, voting behaviour, and coverage. The personalisation of the campaign coverage is referred to as media personalisation and describes the concentration of the election campaign coverage on the Spitzenkandidaten (Brettschneider, 2002). Media personalisation is usually studied along two dimensions: Individualisation describes the content-related shift from institutions/ parties to persons/politicians and Privatisation refers to the shift of the evaluation of politicians based on political traits to non-political/private traits (Brettschneider, 2014; van Aelst, Sheafer, \& Stanyer, 2012). While there is common consent concerning these two dimensions, their operationalisations in empirical studies and their results vary greatly. ${ }^{1}$

The media personalisation of EP elections has rarely been tested empirically and cross-national comparative studies of media personalisation are rare. The very few studies that analyse the coverage of candidates and politicians in the context of EP elections merely include the visibility of European actors relative to national actors. All of them came to a similar conclusion: the visibility of European actors increases over time but national actors are still reported on more frequently (Brettschneider \& Rettich, 2005; Peter \& de Vreese, 2004; Schuck, Xezonakis, Elenbaas, Banducci, \& de Vreese, 2011; Wilke \& Reinemann, 2005). Preliminary research analysing the press coverage of the 2014 EP-elections also finds an increase in the visibility of the Spitzenkandidaten over time (Gattermann, 2015).

The large number of studies analysing this phenomenon in the context of national elections allows for a comprehensive observation of certain trends and features with regards to Germany, France, and the United Kingdom. In general, French election campaign coverage

${ }^{1} \mathrm{~A}$ detailed discussion of the different operationalisation types is presented by Adam and Maier (2010) and van Aelst et al. (2012). 
exhibits the largest degree of media personalisation (e.g. Dalton, McAllister, \& Wattenberg, 2000; Kriesi, 2012). Results for British coverage are mixed, but overall a moderate degree of media personalisation is inferred (e.g. Dalton et al., 2000; Karvonen, 2010; Kriesi, 2012). Hardly any media personalisation was found in German election campaign coverage (e.g. Holtz-Bacha, Langer, \& Merkle, 2014; Leidecker \& Wilke, 2015; Plasser, Pallaver, \& Lengauer, 2009; Zeh \& Schulz, 2015). These country-specific variations can, in large part, be explained by the differences in both the political and media systems of each country (Adam \& Maier, 2010; Hallin \& Mancini, 2004; Holtz-Bacha et al., 2014). Cross-national comparative studies evaluate these system-specific differences to be more relevant than transnational comparative factors such as the difference between quality and tabloid newspapers (Jebril et al., 2013; Karvonen, 2010; Kriesi, 2012; Vliegenthart, Boomgaarden, \& Boumans, 2011). All in all, however, the majority of the latest studies analysing media personalisation conclude that the situational factors-e.g. specific candidates, campaign novelties like debates, or campaign topics-of each election matter the most (e.g. Brettschneider, 2002; Kriesi, 2012; Vliegenthart et al., 2011; Zeh \& Schulz, 2015). Additionally, Gattermann (2015) concludes that the political and media system related differences of these countries cannot explain the differences in the visibility of the Spitzenkandidaten.

The nomination of the Spitzenkandidaten was expected to personalise the EP election campaign, which should then increase the general interest in the EP elections and, as a consequence, boost voter turnout. Analysing the media personalisation in the context of the 2014 EP elections, therefore, offers the opportunity to evaluate and discuss the novelty of the Spitzenkandidaten and its implications. Considering the pan-European character of the Spitzenkandidaten, their campaign, and novel campaign events like the TV debates as well as the general increase of voter participation in the three countries, cross-national similarities in the coverage can be assumed. On the other hand, reasons for possible countryrelated differences need to be taken into account like the differing campaign efforts of the Spitzenkandidaten, the prominence and visibility of the candidates in each country prior to the EP elections, or the large-scale countryspecific differences of the EP election campaign coverage measured in previous research. Therefore, this study aims to analyse the similarities and differences concerning the visibility and personalisation of the Spitzenkandidaten in the EP election campaign coverage in Germany, France, and the United Kingdom (RQ2).

\section{Methodology}

In order to analyse the coverage of the EP elections and the pan-European Spitzenkandidaten, data was collected via a quantitative content analysis of the national daily press coverage in Germany, France, and the United Kingdom. ${ }^{2}$ To approximately represent the wide array of the newspaper landscape for each country three different national daily newspapers were subject to coding: Two quality newspapers, one from each political leaning (simplified) and one tabloid ${ }^{3}$ (see Table 1). Each of these newspapers exhibits the highest circulation numbers in its category and can thus be assumed to hold a central opinion and discourse-leading position in its country.

Since the EP elections receive comparatively little media attention and also bearing in mind the campaign activities of the Spitzenkandidaten, this study focuses solely on the final weeks of the election campaign. During this period, the EP election and the commission candidates are expected to receive the most extensive media attention. In order to facilitate comparability to studies with a similar research interest, the sample period was set to three weeks prior to the elections (Holtz-Bacha et al., 2014; Schuck, Xezonakis et al., 2011;

Table 1. Newspapers per country selected for analysis.

\begin{tabular}{llll}
\hline Newspaper & Country & Political Leaning & Tabloid \\
\hline Sueddeutsche Zeitung & Germany & Left & No \\
Frankfurter Allgemeine Zeitung & Germany & Right & No \\
Bild & Germany & Right & Yes \\
The Guardian & United Kingdom & Left & No \\
The Daily Telegraph & United Kingdom & Right & No \\
The Sun & United Kingdom & Right & Yes \\
Le Monde & France & Left & No \\
Le Figaro & France & Right & No \\
Le Parisien/Ajourd'hui en France & France & Right & Yes \\
\hline
\end{tabular}

\footnotetext{
${ }^{2}$ Though television is usually reported to be the most important source of information for election news (Plasser et al., 2009), newspaper coverage was selected as the most suitable medium for analysis. Compared to TV it can be used for a more conservative test of media personalisation and research found no significant differences concerning the visibility in newspaper and TV
}

coverage (Boomgaarden et al., 2013; Mughan, 2000).

${ }^{3}$ There is no exact tabloid counterpart to Bild and The Sun in France. Le Parisien/Aujourd'hui en France however is characterised by simplified and image-intensive reporting and, therefore, best suited for the comparison (Leidenberger \& Koch, 2008). 
Strömbäck et al., 2011). The election dates, however, differed from country to country which is why the exact sample periods had to be adapted accordingly: articles from British newspapers were published in the period of May 1 to May 21, while the French and German articles were published between May 5 and May 24.

The unit of analysis was, therefore, each article (headline and text) discussing the Spitzenkandidaten or the 2014 EP elections published in the printed edition of the selected newspapers during the three weeks prior to the elections. However, each article mentioning one or several of the Spitzenkandidaten also referred to the EP elections in general. The articles were obtained through the online databases Factiva and Nexis, as well as from the online archive of the Frankfurter Allgemeine Zeitung. After disregarding redundant and irrelevant articles, 532 articles underwent the entire coding procedure.

The cross-national comparative research design offers the possibility of a broader perspective and thus a deeper approach to the results' discussion and empirical insights. However, compared to single-case studies, comparative studies are concerned with one particular methodological challenge crucial to the reliability and validity of the research undertaking: equivalence. To discuss equivalence is to ensure the adequate comparability of the results in the differing systems and to avoid methodological artefacts (Vliegenthart, 2012; Wirth \& Kolb, 2012). While there are several statistical means to test the quality of cross-national surveys computationally, there are none suited for this content analysis (Rössler, 2012). But each step of the research process has been carefully evaluated with respect to the equivalence criteria. Thus, equivalence can be assumed.

\subsection{Operationalisation and Codebook}

The article analysis is based on a detailed codebook consisting of formal and content-related categories. The formal categories allowed the correct allocation of each article as well as a general description of the coverage and included the variables: country, newspaper, date, page number, and article length. The content-related variables are divided into two sub-categories: the EP election campaign coverage in general and the media personalisation of the Spitzenkandidaten in particular.

Referring to RQ1, the EP election coverage is described on the basis of the variables visibility, topic, and perspective. The visibility is understood as the number of articles referring to the EP elections. For each article a maximum of three topics (one main topic and two additional topics) can be coded. The order of coding follows a hierarchical approach: thus there are three main

\footnotetext{
${ }^{4}$ Formal categories: Krippendorff's alpha $=1$ both for intercoder and researcher coder reliability. Content related categories: Krippendorff's alpha for topic $=0.7$, perspective $=0.7$, visibility $=1$, focus $=0.7$, politicians $\&$ parties $=0.9$, characteristics $=0.8$, private
}

attributes-'Politics in general', 'EP Elections' and 'People' - with each four to eight different sub-attributes based on similar studies from Wilke and Reinemann (2005) and Kalantzi (2004), as well as the PIREDEU-codebook (Schuck, Xezonakis, Banducci, \& de Vreese, 2010). The perspective further describes the main topic explaining from which viewpoint the respective topic was discussed and comprises the attributes 'EU perspective', 'national perspective', and 'external perspective'. The last two attributes may differ depending on the country in which the article has been published. For example, an article published in a British newspaper discussing the main topic with relation to its consequences for the UK would be coded as 'national perspective'. On the other hand, an article in a French newspaper presenting the main topic strictly referring to Germany is to be coded as 'external perspective'.

Since media personalisation is a multi-dimensional construct, personalisation is measured based on several categories. In order to generally understand the presence of the Spitzenkandidaten in the coverage, visibility measures the frequency of the articles mentioning their names and is therefore counted for each article. Repeated mentions of the same actor within one article are not counted. With respect to the theoretical definition, the two main categories to analyse the media personalisation are individualisation (from institution/parties to persons/politicians) and privatisation (from political traits to non-political/private traits). Individualisation is measured via the variable focus that analyses the actor at the centre of each article with respect to the attributes 'national parties', 'EU parties/factions', 'Spitzenkandidaten', 'other EU politicians', 'national politicians', and 'international politicians'. Privatisation comprises the categories characteristics and personal life. The coding scheme for both categories are based on the suggestions of van Aelst et al. (2012, p. 219f), and were slightly amended and translated. The attributes for characteristics include 'competence', 'leadership', 'credibility', 'morality', 'appearance', and 'rhetorical skills'. For each attribute it was coded if the characteristic was mentioned with relation to the political or personal context of the Spitzenkandidat. The category personal life entails the attributes 'family life', 'past life', 'leisure time', and 'love life'.

Referring to the equivalence criteria, the codebook and the whole coding process relied on one common reference language: German. Thus, the coders, one per country, were German native speakers with excellent foreign language skills. They underwent extensive multilevel coder training that resulted in satisfactory reliability values. ${ }^{4}$

life $=1$ for intercoder reliability. Krippendorff's alpha for topic $=0.7$, perspective $=0.7$, visibility $=1$, focus $=0.7$, politicians \& parties $=0.9$, characteristics $=0.9$, private life $=1$ for researcher coder reliability. 


\section{Results}

\subsection{Newspaper Coverage of the 2014 EP Election}

\subsubsection{Visibility}

Altogether, the EP elections were mentioned in 532 articles in the course of the three weeks prior to the day of the election. Since Sundays were excluded from this analysis, this amounts to an average of 3.3 articles per day per newspaper. However, a more detailed analysis in Figure 1 reveals country- and media-specific differences. The French newspapers discussed the EP elections most frequently (FR: 222 articles), closely followed by the German newspapers (DE: 193 articles). Substantially less attention was given by the British newspapers (UK: 117 articles). Comparing media-related differences, it becomes obvious that the EP elections are far more visible in the quality press than in the tabloids.

The analysis of the article count over time shows that the daily amount of articles is subject to large fluctuations, though the daily amount of articles follows a similar shape in all three countries. While there are several peaks, which might be the result of similar Europewide campaign events, there is a steady increase in coverage depth. Especially during the last eight to five days before the election the interest of the media in terms of article numbers increases markedly due to the proximity of the event.

\subsubsection{Topic and Perspective}

The broad analysis of the main topic shows that the EP elections are the central aspect of more than half of the articles (53\%), while a third of the articles refer to politics in general $(34 \%)$ and $12 \%$ of the articles portray one person or several people. Table 2 presents the in-depth analysis of the main topic for the entire sample and each country separately. Looking in detail, the EP elections are primarily discussed in relation to the topics 'EP election campaign, campaigning and TV debates' and 'Euroscepticism'. The country-specific analysis shows varying thematic foci: The British coverage primarily focuses on issues related to 'domestic politics \& administration' as well as the 'EP election campaign'. The German coverage is, with the exception of the 'EP election campaign', relatively balanced and multifaceted. The main topics of the French coverage differ clearly from the other two countries: while 'domestic politics' is rarely reported, 'economy \& finance' appears to be the most important issue-even trumping the election campaign itself while 'Euroscepticism' and 'politicians' profiles' are of relatively exceptional relevance in the French newspapers.

The perspective of the article refers to the viewpoint from which the main topic is discussed. Table 3 points out the country-specific differences concerning the choice of perspective for the discussion of each broad category of the main topic and thus how often each main topic is

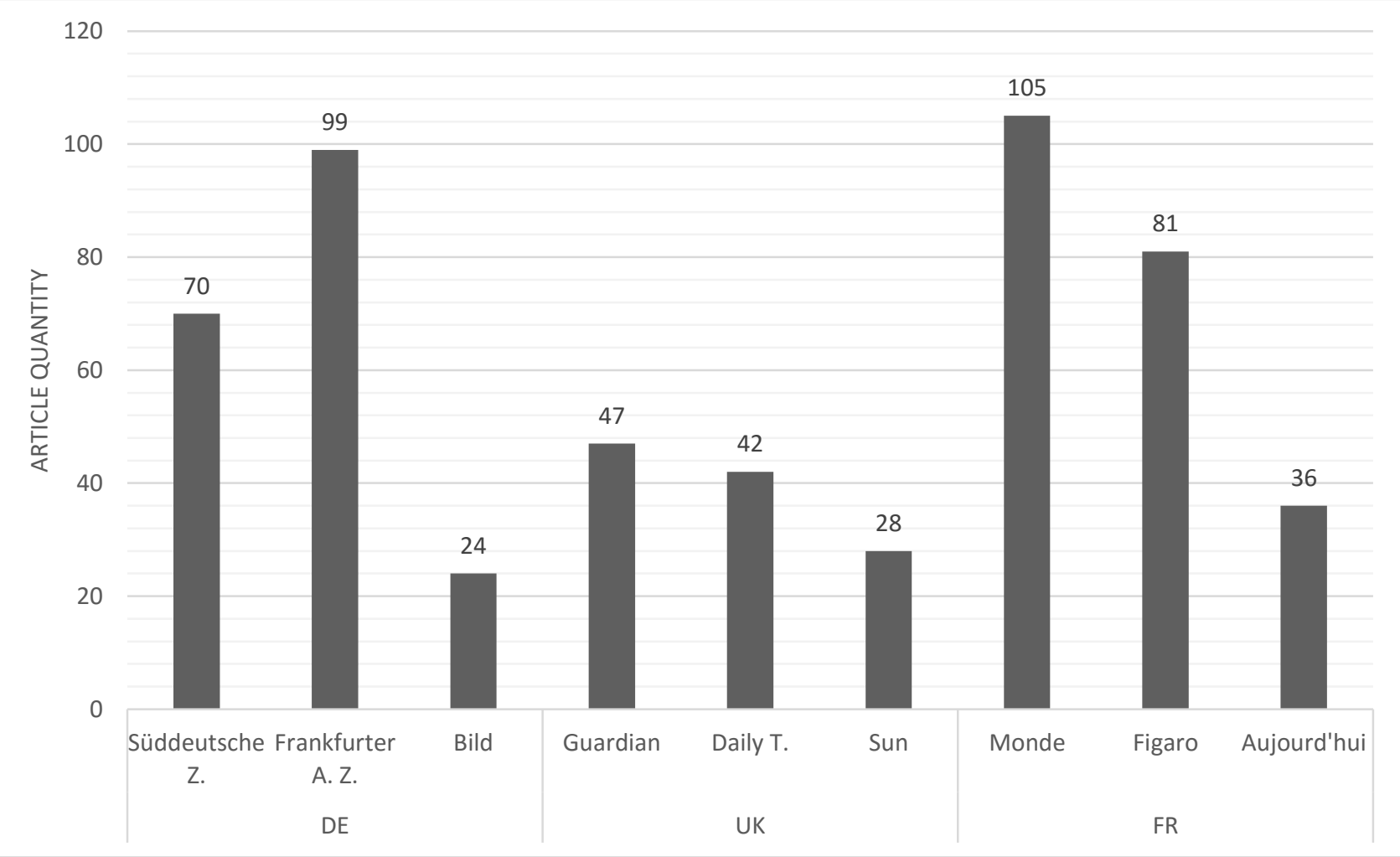

Figure 1. Quantity of articles per newspaper and country ( $N=532)$. 
Table 2. The main topics in total and per country in \%.

\begin{tabular}{lrrrr}
\hline Main Topic & Total & DE & UK & FR \\
\hline EP election campaign & 24.4 & 28.5 & 33.3 & 16.2 \\
Economy \& finance & 11.7 & 7.8 & 6.0 & 18.0 \\
Domestic politics \& administration & 10.2 & 9.3 & 24.8 & 3.2 \\
Profiles of politicians & 8.3 & 6.2 & 2.6 & 13.1 \\
Euroscepticism & 5.8 & 3.1 & 2.6 & 9.9 \\
Foreign politics & 5.5 & 6.2 & 2.6 & 6.3 \\
Polls & 4.9 & 3.6 & 4.3 & 6.3 \\
\hline
\end{tabular}

Note: Per article one main topic was coded; topics that were only present in less than $5 \%$ of the articles within each group are not listed due to their lack of relevance; $n(D E)=125 ; n(U K)=104 ; n(F R)=109 ; N=532$.

Table 3. Perspective of the main topic in \%.

\begin{tabular}{lccccccccc}
\hline \multirow{2}{*}{ Topics } & \multicolumn{3}{c}{ EU-perspective } & \multicolumn{3}{c}{ National perspective } & \multicolumn{3}{c}{ External perspective } \\
\cline { 2 - 10 } & DE & UK & FR & DE & UK & FR & DE & UK & FR \\
\hline Politics in general & 40.3 & 10.6 & 39.4 & 30.6 & 85.1 & 45.1 & 25.8 & 4.3 & 15.5 \\
EP elections & 32.4 & 9.5 & 25.7 & 33.3 & 85.7 & 60.2 & 34.3 & 3.2 & 14.2 \\
People & 47.6 & - & 2.6 & 33.3 & 85.7 & 71.1 & 19.0 & 14.3 & 26.3 \\
Total & 37.3 & 9.4 & 26.1 & 32.1 & 85.5 & 57.2 & 29.5 & 4.3 & 16.7 \\
\hline
\end{tabular}

Note: The reference point concerning 'national' and 'external' varies with regard to each country; in $0,6 \%$ of the articles the perspective was ambivalent; each topic per country adds up to $100 \% ; n(D E)=125 ; n(U K)=104 ; n(F R)=109 ; N=532$.

discussed from which perspective in each country. The German coverage is, in general, quite balanced measured against the perspective from which the topics are discussed. However, the EU-perspective prevails minimally. The British coverage on the other hand shows the strongest national focus and rarely discusses topics from a different angle. French newspapers also reflect the topics from a national perspective more frequently; only a fourth of the articles assumed the perspective of the EU and its institutions. Additionally, the media-specific differences are quite distinct: though following the country's generally preferred perspective, in all countries the tabloids discuss the main topics much more frequently from a national perspective than the quality newspapers.

\subsection{Newspaper Coverage of the Spitzenkandidaten}

\subsubsection{Visibility of the Spitzenkandidaten}

A minority of articles referring to the EP elections mention one of the Spitzenkandidaten (21.1\%). The countryspecific differences are nevertheless pronounced: while the British coverage barely mentions the candidates at all (2.6\%), around a fifth of the French articles about the EP elections (18\%) names them, and the German coverage discusses them most frequently (35.8\%). Figure 2 visualises the country- and media-specific differences. The tabloids present the Spitzenkandidaten substantially less frequently than the quality newspapers.

In general, the Spitzenkandidaten are not very visible in the newspaper coverage prior to the EP elections. The entire EP election campaign coverage contains 193 candidate mentions. Schulz $(n=86 ; 16.2 \%)$ and Juncker $(n=66 ; 12.4 \%)$ are mentioned most frequently across all countries. Verhofstadt $(n=21 ; 3.9 \%)$ and Tsipras $(n=15$; $2.8 \%)$ receive considerably less mentions while Keller is virtually invisible ( $n=5 ; 0.9 \%)$. With respect to countryspecific differences, it becomes apparent that the German media predominantly focuses on Schulz and Juncker while the candidates of the smaller factions are scarcely mentioned. The French coverage on the other hand, while also mentioning Schulz and Juncker more frequently, discusses the candidates of the smaller factions more prominently and presents a broader and more balanced coverage of the Spitzenkandidaten than the German newspapers.

\subsubsection{Individualisation}

Individualisation describes the shift of media attention from parties to politicians. It is measured via the variable focus that analyses the main actors of the coverage. Table 4 highlights the percentile frequency of the main actors for each country and the entire sample with respect to parties and politicians in general as well as in greater detail. In general, politicians were more frequently at the centre of the coverage than parties. The French coverage displays the highest ratio of politician to party-focus-politicians, then, function as the central actors more than twice as frequently as parties. The British newspapers also focus predominantly on politicians, though a little less so than the French. While still focusing on politicians as well, German newspapers present the lowest degree of individualisation. 


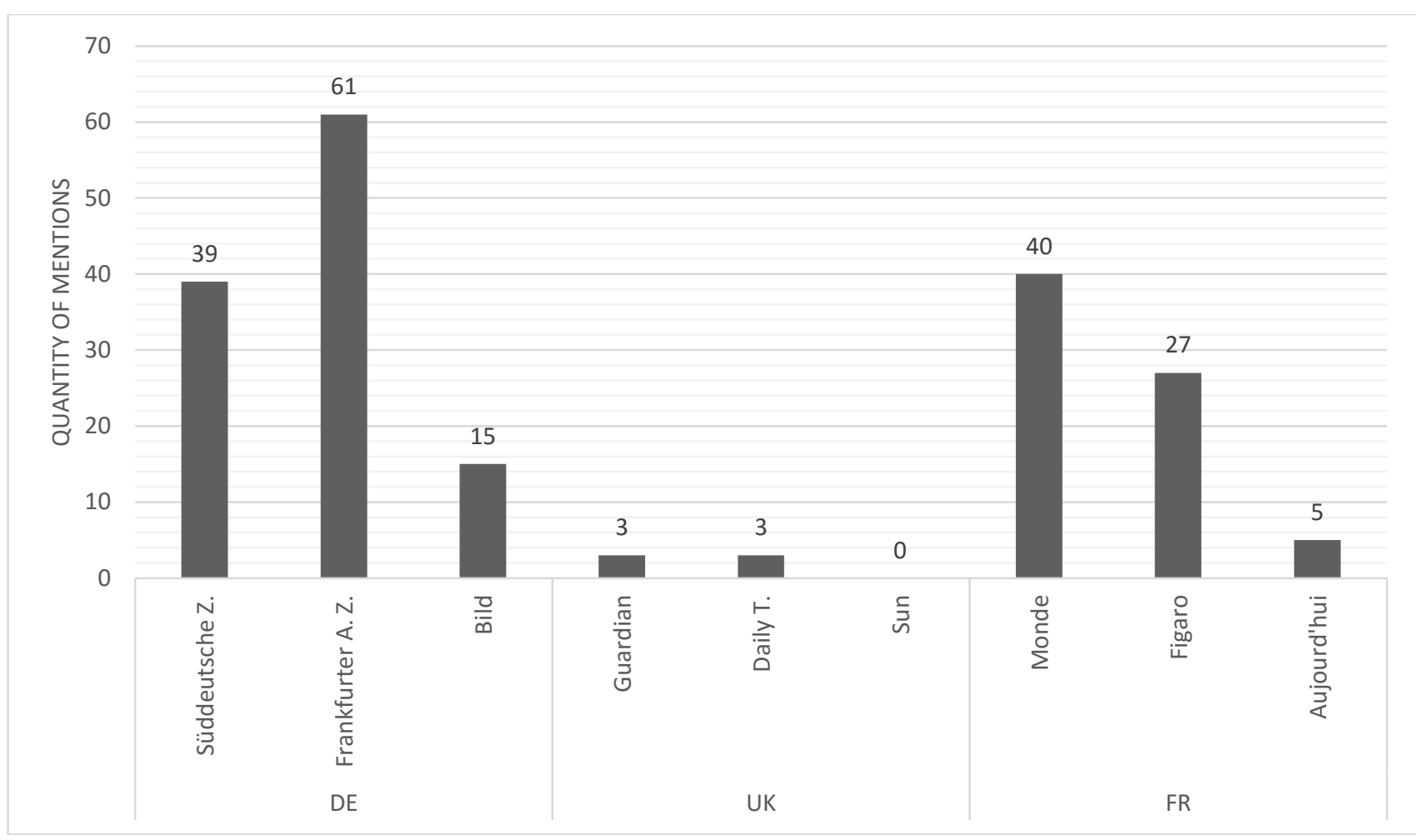

Figure 2. Visibility of the Spitzenkandidaten per newspaper and per country ( $N=532)$.

Table 4. Main actor (focus) in \%.

\begin{tabular}{lrrrr}
\hline Main actor (focus) & Total & DE & UK & FR \\
\hline National parties & 22.2 & 24.9 & 30.8 & 15.3 \\
EU-parties & 0.8 & 1.0 & 1.7 & 0.0 \\
Total parties & $\mathbf{2 3 . 0}$ & $\mathbf{2 5 . 9}$ & $\mathbf{3 2 . 5}$ & $\mathbf{1 5 . 3}$ \\
Spitzenkandidaten & 7.5 & 16.6 & 0.0 & 3.6 \\
Other EU-politicians & 12.4 & 9.3 & 23.9 & 9.0 \\
National politicians & 15.0 & 5.7 & 30.8 & 14.9 \\
International politicians & 5.6 & 7.3 & $\mathbf{3 6 . 4}$ & 6.3 \\
Total politicians & $\mathbf{4 0 . 5}$ & $\mathbf{3 8 . 9}$ & $\mathbf{5 3 . 8}$ \\
\hline
\end{tabular}

Note: The reference point concerning 'national' and 'international' varies with regard to each country; $n(D E)=125 ; n(U K)=$ $104 ; n(F R)=109 ; N=532$.

Concerning the relevance of the Spitzenkandidaten, the analysis of the focus supports the previous findings: the British coverage did not put any Spitzenkandidat at the centre of any article but instead covered other EU and national politicians in depth. The French newspapers discussed the actions of a few of them in greater detail but, similarly to the United Kingdom, preferred to present other EU and national politicians. The German coverage emphasised the Spitzenkandidaten the most. All in all, in comparison to the parties, the Spitzenkandidaten are barely visible.

\subsubsection{Privatisation}

Privatisation refers to the characteristics (political vs. personal) and the private life of the Spitzenkandidaten. About half of all articles mentioning a candidate discussed certain political and personal characteristics of each one (68 articles). The German coverage comprises the vast majority of these character references (153), the French considerably less (92), and the British newspapers almost none (11). In relation to the amount of candidate mentions, however, the British newspapers covered characteristics more frequently than the other two countries.

The 256 different character references predominantly involved the characteristics 'competence' (65) and 'leadership' (68). The majority of the references showed characteristics with respect to the political arena of the candidate. Only five character references involved their private lives. Concerning the different candidates, Schulz's (103), and Juncker's (103) character traits were covered most frequently (see Figure 3 ). A particular emphasis on one certain character trait of a particular candidate cannot be found. 


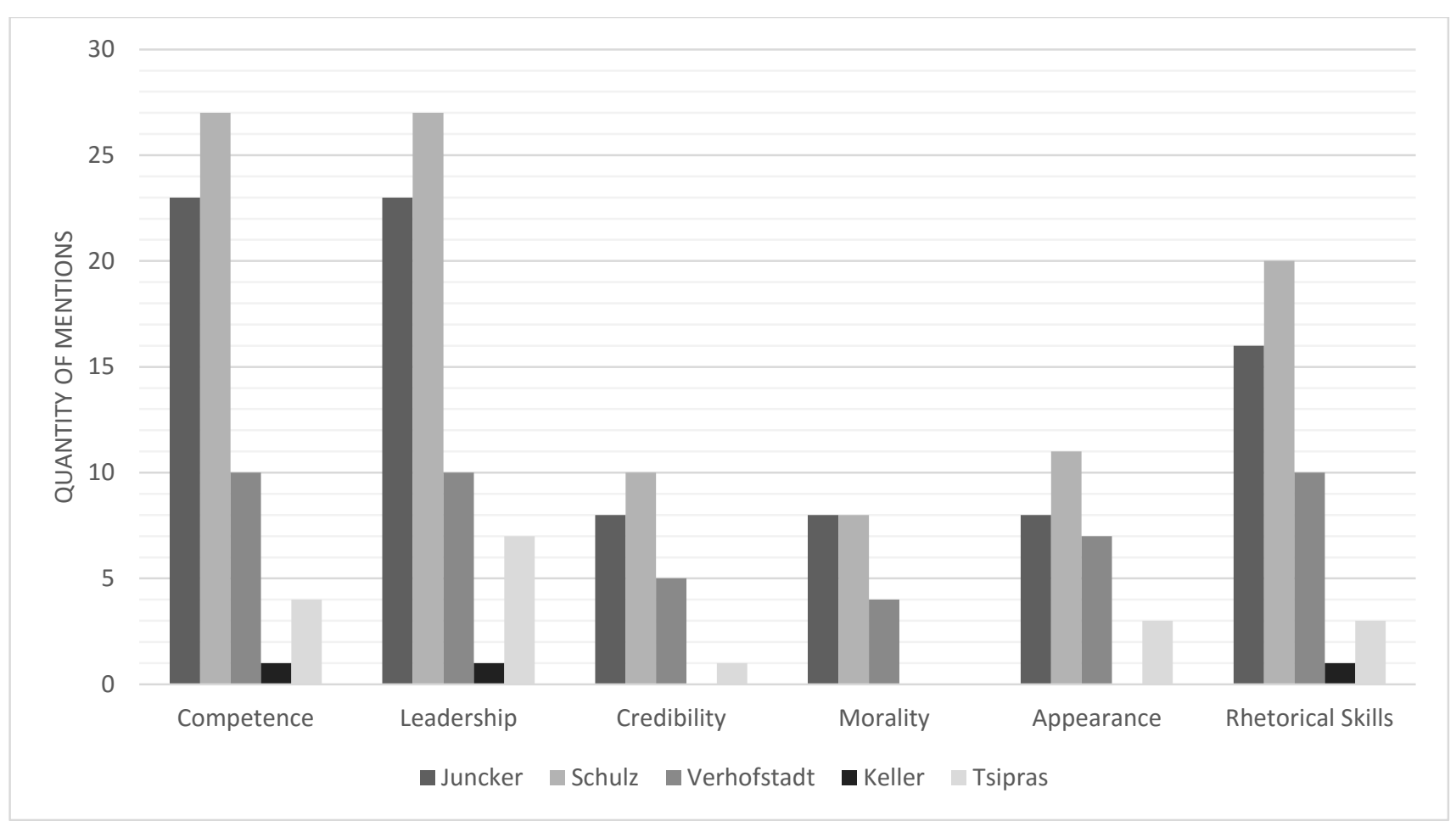

Figure 3. Characteristics per Spitzenkandidat ( $N=532)$.

The private lives of the Spitzenkandidaten were barely covered by the newspapers. Altogether only seven articles included one or more references to a candidate's private life (eleven in total). Thus, only $1.3 \%$ of the articles portrayed private aspects of the Spitzenkandidaten. The majority of the mentions referred to biographical details while their love life was not discussed at all.

\section{Discussion}

The analysis of the EP election campaign coverage across three countries portrays a highly diverse picture. The general amount of articles discussing the EP elections and thus, the visibility of the campaign, appears to adequately fulfil the task of informing and mobilising the voter. Although this analysis does not offer precise empirical substantiation in the form of time-series data for this assumption, compared to previous studies the general media attention towards the EP election seems to have increased (Peter, 2004; Strömbäck et al., 2011). This result would be consistent with various other studies that found an increase in the media coverage of EP elections (Boomgaarden et al., 2010; de Vreese et al., 2006; Schuck, Azrout et al., 2011; Schuck, Xezonakis et al., 2011; Vliegenthart et al., 2008). Concerning the detailed analysis of the content related categories topic and the perspective, this study's results are highly similar to those of analyses of previous EP election campaigns. This shows that the presence of the Spitzenkandidaten hardly affected the way the national media cover the EP election campaigns in general. As in previous studies, large-scale country-related differences in the media coverage of the EP elections were found (e.g. Peter, Lauf, \& Semetko, 2004; Schuck, Azrout et al., 2011; Strömbäck et al., 2011). German coverage appears the most Europhile: The EP election campaign is quite visible not only with respect to the amount of articles that cover it but also in relation to the main topic focusing on the campaign itself. The majority of the issues are discussed from a European perspective. This result is the only one that is different from previous studies, which have found the German coverage to predominantly discuss the national perspective (e.g. Adam, 2007; Lozac'h, 2007; Tenscher, 2006; Voltmer \& Eilders, 2003). French newspapers reported most frequently about the EP elections with respect to the amount of articles. Nevertheless, economy and finance were covered more often than the EP elections, and also Euroscepticism seemed to be an important topic of the public debate. While in general most articles were discussed from the national viewpoint, finance was equally covered from the national and EU perspective. It can therefore be assumed that the European debt crisis was of central concern, which previous studies found to positively influence the media attention towards the EU (Kriesi \& Grande, 2014 in Hobolt, 2014). British newspapers covered the EP elections far less frequently than the German and French media and, similarly to the French coverage, almost all topics were debated from a national perspective. The majority of those country-related differences could be explained by the general attitude of the respective country's public towards the European Union, with the Germans supporting their EU membership the most and the British people the least 
(Bruter \& Harrison, 2007; Lozac'h, 2007; Negrine, 2006). Compared to the overall visibility of the EP election campaign in the coverage as well as the usual role of senior candidates during national elections, the Spitzenkandidaten appeared more as a side issue than as the centre of media attention. While British newspapers hardly covered the Spitzenkandidaten at all, French and German media paid a far higher amount of attention to the Spitzenkandidaten, which, however, was still low compared to national elections. Possible explanations for this could be again the attitude towards the EU membership but also the campaign efforts of the Spitzenkandidaten who focused especially on France and Germany while neglecting the United Kingdom. Furthermore, the German and French coverage predominantly focused on Schulz and Juncker, the candidates of the two main political groups in the European Parliament. It seems that the media embraced those candidates who were most likely to become the next president of the European Commission. Additionally, the position of Schulz as President of the EP explains why he was covered slightly more frequently than Juncker who was less visible as chairman of the Eurogroup. German newspapers in particular emphasised these candidates at the expense of candidates from the smaller parties who were barely mentioned, while the French coverage, by contrast, reported in a slightly more balanced manner and referred to the candidates of the smaller parties more frequently. This is especially surprising with respect to Ska Keller, a German politician who against all odds was more visible in the French than the German coverage. However, this result is in line with previous research of German election news coverage that regularly demonstrates a strong incumbent bonus, due to its relevance also referred to as chancellor bonus (Zeh \& Schulz, 2015).

Nevertheless, in all three countries, the campaign coverage of the Spitzenkandidaten can hardly be understood as personalised with respect to the Spitzenkandidaten. Despite different findings from previous personalisation research, in this study the German coverage displays the highest degree of media personalisation concerning the Spitzenkandidaten (e.g. Holtz-Bacha et al., 2014). This indicates that the country-specific differences in media personalisation with respect to the Spitzenkandidaten can barely be explained by the factors that are usually used for comparing media personalisation in the context of national elections. The political and media system-related differences in personalisation are not reflected in the coverage of the Spitzenkandidaten (Adam \& Maier, 2010; Hallin \& Mancini, 2004; Holtz-Bacha et al., 2014; Gattermann, 2015). Moreover, the degree of personalisation appears to be directly related to the number of candidate mentions as well as the preferred perspective for the EP election campaign coverage. The German coverage, which contained the most candidate references, also reported most frequently from a European perspective. The British coverage, on the other hand, hardly mentioned the Spitzenkandidaten and discussed the main topics predominantly from a national perspective. These differences may possibly be explained by the general attitude of each country towards the EU in general or the European elections in particular and by the number of candidate's campaigning visits in different European countries.

\section{Conclusions}

At first glance, the 2014 Elections to the European Parliament differed greatly from all previous EP elections. For the first time, pan-European Spitzenkandidaten were nominated and were expected to raise the general interest in EP elections and mobilise European voters. Based on this development, this study analysed the media coverage of the EP elections in general and specifically with respect to the coverage of Spitzenkandidaten in Germany, France, and the United Kingdom. Altogether, the results demonstrate an adequate visibility of the 2014 EP election campaign in the newspaper coverage. Still, compared to the visibility of the EP election campaign in general, only a relatively small amount of the coverage discussed the Spitzenkandidaten and, compared to the usual amount of media personalisation during national elections, the coverage does not display personalising effects. This leads to the conclusion that the high expectations connected to their nomination were not reflected in the media coverage of them. However, one can hypothesise that the presence of the Spitzenkandidaten may have contributed indirectly to an increase in media attention towards the EP elections since the novelty of their nomination and campaign activities within the EP elections process raised the approximate number of topics relevant to the electorate and the media, and consequently, the general relevance of the EP elections. Furthermore, expecting an electoral procedure as complex and diverse as the one represented by the EP elections, encompassing voters from 28 member states, to change in the course of just one election appears overly ambitious. It might be too early, therefore, for an extensive evaluation of the effect of the Spitzenkandidaten at this point in time, which is why these developments will have to be monitored closely during future elections.

\section{Acknowledgements}

The author expresses her deepest gratitude towards Professor Wolfgang Donsbach and Dr. Anna-Maria Schielicke for supervising the research for this study and their encouragement to publish the results. For their feedback and helpful remarks on the draft, she thanks Lisa Merten and Sarah Hartleib. Additionally, she gives thanks to the IfK Förderverein Dresden (friends' association of the Department of Communication Research at 
TU Dresden) who supported this study financially. Additionally, she acknowledges support by the German Research Foundation and the Open Access Publication Funds of the TU Dresden.

\section{Conflict of Interests}

The author declares no conflict of interests.

\section{References}

Adam, S. (2007). Symbolische Netzwerke in Europa: Der Einfluss der nationalen Ebene auf europäische Öffentlichkeit; Deutschland und Frankreich im Vergleich (1st ed.). Cologne, Germany: Von Halem.

Adam, S., \& Maier, M. (2010). Personalization of politics: A critical review and agenda for research. In C. T. Salmon (Ed.), Communication yearbook 34 (pp. 212257). London: Routledge.

Banducci, S. A., \& Semetko, H. A. (2003). Media and mobilization in the 1999 European Parliamentary election. In M. Bond (Ed.), The federal trust series. Future of European parliamentary democracy: Vol. 5. Europe, parliament and the media (pp. 189-203). London: Kogan Page.

Bentele, G., \& Fähnrich, B. (2010). Personalisierung als sozialer Mechanismus in Medien und gesellschaftlichen Organisationen. In M. Eisenegger \& S. Wehmeier (Eds.), Organisationskommunikation. Personalisierung der Organisationskommunikation. Theoretische Zugänge, Empirie und Praxis (pp. 51-75). Wiesbaden, Germany: Springer VS.

Boomgaarden, H. G., de Vreese, C. H., Schuck, A. R. T., Azrout, R., Elenbaas, M., Van Spanje, J. H.P., \& Vliegenthart, R. (2013). Across time and space: Explaining variation in news coverage of the European Union. European Journal for Political Research, 52(5), 608-629. doi:10.1111/1475-6765.12009

Boomgaarden, H. G., Vliegenthart, R., de Vreese, C. H., \& Schuck, A. R. T. (2010). News on the move: Exogenous events and news coverage of the European Union. Journal of European Public Policy, 17(4), 506-526. doi:10.1080/13501761003673294

Brettschneider, F. (2002). Spitzenkandidaten und Wahlerfolg: Personalisierung, Kompetenz, Parteien; Ein internationaler Vergleich (1st ed.). Wiesbaden, Germany: Westdeutscher Verlag.

Brettschneider, F. (2014). Massenmedien und Wählerverhalten. In J. W. Falter \& H. Schoen (Eds.), Handbuch Wahlforschung (pp. 625-657). Wiesbaden, Germany: Springer Fachmedien Wiesbaden.

Brettschneider, F., \& Rettich, M. (2005). Europa-(k)ein Thema für die Medien. In J. Tenscher (Ed.), WahlKampf um Europa. Analysen aus anlass der wahlen zum Europäischen Parlament 2004 (pp. 136-156). Wiesbaden, Germany: Springer VS.

Bruter, M., \& Harrison, S. (2007). United Kingdom. In Y.
Déloye \& M. Bruter (Eds.), Encyclopaedia of European elections (pp. 485-489). Basingstoke, New York: Palgrave Macmillan.

Cassel, S., \& Thomas, T. (2014). Europawahl 2014-Quo vadis Europa? (Econwatch Policy Brief, 5/14). Berlin: Econwatch.

Chaucheprat, M. (2014). The 2014 European elections: This time it's different. European Parliament. Retrieved from http://www.europarl.europa.eu/news/ de/news-room/content/20140210BKG35568/html/ THE-2014-EUROPEAN-ELECTIONS-THIS-TIME-IT\%E2\% 80\%99S-DIFFERENT

Dalton, R. J., McAllister, I., \& Wattenberg, M. P. (2000). The consequences of partisan dealignment. In R. J. Dalton \& M. P. Wattenberg (Eds.), Comparative politics. Parties without partisans. Political change in advanced industrial democracies (pp. 37-63). Oxford, New York: Oxford University Press.

de Vreese, C. H., Banducci, S. A., Semetko, H. A., \& Boomgaarden, H. G. (2006). The news coverage of the 2004 European Parliamentary election campaign in 25 countries. European Union Politics, 7(4), 477-504. doi:10.1177/1465116506069440

de Vreese, C. H., \& Boomgaarden, H. (2006). News, political knowledge and participation: The differential effects of news media exposure on political knowledge and participation. Acta Politica, 41(4), 317-341. doi:10.1057/palgrave.ap.5500164

Gattermann, K. (2015). Europäische Spitzenkandidaten und deren (Un-)Sichtbarkeit in der nationalen Zeitungsberichterstattung. In M. Kaeding \& N. Switek (Eds.), Die Europawahl 2014. Spitzenkandidaten, Protestparteien, Nichtwähler (pp. 211-222). Wiesbaden, Germany: Springer VS.

Gerstlé, J., Magni-Berton, R., \& Piar, C. (2006). Media coverage and voting in European Parliamentary Elections in France 2004. In M. Maier \& J. Tenscher (Eds.), Campaigning in Europe-Campaigning for Europe. Political parties, campaigns, mass media and the European parliament elections 2004 (pp. 339-352). Berlin, Germany: LIT.

Hallin, D. C., \& Mancini, P. (2004). Comparing media systems: Three models of media and politics. Communication, society, and politics. Cambridge: Cambridge University Press.

Hobolt, S. B. (2014). A vote for the president? The role of Spitzenkandidaten in the 2014 European Parliament elections. Journal of European Public Policy, 21(10), 1528-1540. doi:10.1080/13501763.2014.941148

Hobolt, S. B., Spoon, J.-J., \& Tilley, J. (2009). A vote against Europe? Explaining defection at the 1999 and 2004 European Parliament elections. British Journal of Political Science, 39(1), 93. doi:10.1017/S0007123 408000422

Holtz-Bacha, C., Langer, A. I., \& Merkle, S. (2014). The personalization of politics in comparative perspective: 
Campaign coverage in Germany and the United Kingdom. European Journal of Communication, 29(2), 153170. doi:10.1177/0267323113516727

Huss, T. (2007). Personalisierung von Politik: Kandidatenorientierung und Wahlverhalten. Saarbrücken, Germany: VDM, Müller.

Jebril, N., Albaek, E., \& de Vreese, C. H. (2013). Infotainment, cynicism and democracy: The effects of privatization vs personalization in the news. European Journal of Communication, 28(2), 105-121. doi:10. 1177/0267323112468683

Kalantzi, M. (2004). Europa in der Tagespresse Deutschlands und Griechenlands-Ergebnisse einer empirischen Untersuchung. In L. M. Hagen (Ed.), Europäische Union und mediale Öffentlichkeit. Theoretische Perspektiven und empirische Befunde zur Rolle der Medien im europäischen Einigungsprozess (pp. 178194). Cologne, Germany: Halem.

Karvonen, L. (2010). The personalisation of politics: $A$ study of parliamentary democracies. ECPR monographs. Colchester: ECPR Press.

Kriesi, H. (2012). Personalization of national election campaigns. Party Politics, 18(6), 825-844. doi:10.11 77/1354068810389643

Lass, J. (1995). Vorstellungsbilder über Kanzlerkandidaten: Zur Diskussion um die Personalisierung von Politik. Wiesbaden, Germany: DUV.

Leidecker, M., \& Wilke, J. (2015). Langweilig? Wieso langweilig: Die Presseberichterstattung zur Bundestagswahl $2013 \mathrm{im}$ Langzeitvergleich. In C. Holtz-Bacha (Ed.), Die Massenmedien im Wahlkampf. Die Bundestagswahl 2013 (pp. 145-173). Wiesbaden, Germany: Springer VS.

Leidenberger, J., \& Koch, T. (2008). "Bambi und der böse Wolf". Ségolène Royal und der französische Präsidentschaftswahlkampf in der deutschen und französischen Presse. In C. Holtz-Bacha (Ed.), Frauen, Politik und Medien (pp. 122-150). Wiesbaden, Germany: VS, Verl. für Sozialwiss.

Leroy, P., \& Siune, K. (1994). The role of television in European Elections: The cases of Belgium and Denmark. European Journal of Communication, 9(1), 47-69. doi:10.1177/0267323194009001003

Lozac'h, V. (2007). Germany. In Y. Déloye \& M. Bruter (Eds.), Encyclopaedia of European elections (pp. 245249). Basingstoke: Palgrave Macmillan.

Maier, M., \& Maier, J. (2008). News coverage of EU Parliamentary Elections. In J. Strömbäck \& L. L. Kaid (Eds.), ICA handbook series. The handbook of election news coverage around the world (pp. 403-420). New York: Routledge.

Marino, B. (2014). Europarties' choices. Who are the candidates for the presidency of the European Commission and how have they been selected? In L. de Sio, V. Emanuele, \& N. Maggini (Eds.), The European Parliament elections of 2014 (pp. 43-49). Rome, Italy: Centro Italiano Studi Elettorali.
Merkle, S. (2015). Personalisierung und genderspezifische Berichterstattung im Bundestagswahlkampf 2013-'Ausnahmefall' Angela Merkel oder typisch Frau. In C. Holtz-Bacha (Ed.), Die Massenmedien im Wahlkampf. Die Bundestagswahl 2013 (pp. 217-247). Wiesbaden, Germany: Springer VS.

Mughan, A. (2000). Media and the presidentialization of parliamentary elections. Hampshire: Palgrave.

Negrine, R. (2006). The long road to professionalisation. In M. Maier \& J. Tenscher (Eds.), Campaigning in Europe-Campaigning for Europe. Political parties, campaigns, mass media and the European parliament elections 2004 (pp. 31-44). Berlin, Germany: LIT.

Niedermayer, O. (2014). Immer noch eine "nationale Nebenwahl"? Die Wahl zum Europäischen Parlament am 25. Mai 2011. Zeitschrift für Parlamentsforschung, 45(3), 523-546.

Odmalm, P. (2005). Europawahlkampf in Großbritannien oder: Die Kampagne, die es nicht gab. In J. Tenscher (Ed.), Wahl-Kampf um Europa. Analysen aus Anlass der Wahlen zum Europäischen Parlament 2004 (pp. 252-268). Wiesbaden, Germany: Springer VS.

Odmalm, P. (2006). Between absence and populism: The British 2004 EP election. In M. Maier \& J. Tenscher (Eds.), Campaigning in Europe-Campaigning for Europe. Political parties, campaigns, mass media and the European parliament elections 2004 (pp. 67-79). Berlin, Germany: LIT.

Ohr, D. (2000). Wird das Wählerverhalten zunehmend personalisierter, oder: Ist jede Wahl anders? Kandidatenorientierung und Wahlentscheidung in Deutschland von 1961 bis 1998. In M. Klein (Ed.), 50 Jahre empirische Wahlforschung in Deutschland. Entwicklung, Befunde, Perspektiven, Daten (pp. 272-308). Wiesbaden, Germany: Westdeutscher Verlag.

Peter, J. (2004). Kaum vorhanden, thematisch homogen und eher negativ-Die alltägliche Fernsehberichterstattung über die Europäische Union im internationalen Vergleich. In L. M. Hagen (Ed.), Europäische Union und mediale Öffentlichkeit. Theoretische Perspektiven und empirische Befunde zur Rolle der Medien im europäischen Einigungsprozess (pp. 146-161). Cologne, Germany: Halem.

Peter, J., \& de Vreese, C. H. (2004). In search of Europe: A cross-national comparative study of the European Union in national television news. The Harvard International Journal of Press/Politics, 9(4), 3-24. doi:10. 1177/1081180X04270597

Peter, J., Lauf, E., \& Semetko, H. A. (2004). Television coverage of the 1999 European Parliamentary elections. Political Communication, 21(4), 415-433. doi:10. 1080/10584600490518315

Piedrafita, S., \& Renman, V. (2014). The 'personalisation' of the European elections: $A$ half-hearted attempt to increase turnout and democratic legitimacy? (EPIN Papers No. 37). Brussels, Belgium: European Policy Institutes Network. Retrieved from http://ssrn.com/ 
abstract $=2429232$

Plasser, F., Pallaver, G., \& Lengauer, G. (2009). Die (transInationale Nachrichtenlogik in MediendemokratienPolitischer TV-Journalismus im Wahlkampf zwischen transatlantischer Konvergenz und nationaler Divergenz. In F. Marcinkowski \& B. Pfetsch (Eds.), Politische Vierteljahresschrift. Sonderheft: Vol. 42. Politik in der Mediendemokratie (pp. 174-202). Wiesbaden, Germany: Springer VS.

Pop, V. (2014). Buses, selfies, posters: EU campaign in full swing. EU Observer. Retrieved from https://eu observer.com/eu-elections/124152

Rössler, P. (2012). Comparative content analysis. In F. Esser \& T. Hanitzsch (Eds.), ICA handbook series. Handbook of comparative communication research (pp. 459-468). New York: Routledge.

Schmitt, H., Hobolt, S., \& Popa, S. A. (2015). Does personalization increase turnout? Spitzenkandidaten in the 2014 European Parliament elections. European Union Politics, 16(3), 347-368. doi:10.1177/146511 6515584626

Schmitt, H., Hobolt, S. B., \& Popa, S. A. (2014, September). "Spitzenkandidaten" in the 2014 European Parliament Election: Does campaign personalization increase the propensity to turn out? Paper presented at the ECPR General Conference, Glasgow, Scotland.

Schuck, A. R. T., Azrout, R., Boomgaarden, H. G., Elenbaas, M., van Spanje, J., Vliegenthart, R., \& de Vreese, C. H. (2011). Media visibility and framing of the European parliamentary elections 2009: A media content analysis in 27 countries. In M. Maier, J. Strömbäck, \& L. L. Kaid (Eds.), Political communication in European parliamentary elections (pp. 175-196). Farnham, UK: Ashgate.

Schuck, A. R. T., Xezonakis, G., Banducci, S. A., \& de Vreese, C. H. (2010). European Parliament election study 2009, media study. GESIS Data Archive, Cologne. ZA5056 Data file Version 1.0.0. doi:10.4232/ 1.10203.

Schuck, A. R. T., Xezonakis, G., Elenbaas, M., Banducci, S. A., \& de Vreese, C. H. (2011). Party contestation and Europe on the news agenda: The 2009 European parliamentary elections. Electoral Studies, 30(1), 41-52. doi:10.1016/j.electstud.2010.09.021

Semetko, H. A., Blumler, J. G., Gurevitch, M., \& Weaver, D. (1991). The formation of campaign agendas: $A$ comparative analysis of party and media roles in recent American and British elections. Communication. Hillsdale, NJ: Lawrence Erlbaum Associates.

Strömbäck, J., Negrine, R., Hopmann, D. N., Jalali, C., Berganza, R., Seeber, G. U. H....Maier, M. (2013). Sourcing the news: Comparing source use and media framing of the 2009 European Parliamentary elections. Journal of Political Marketing, 12(1), 29-52. doi:10.1080/15377857.2013.752227

Strömbäck, J., Negrine, R., Hopmann, D. N., Maier, M., Ja- lali, C., Berganza, R . . Róka, J. (2011). The mediatization and framing of European Parliamentary Election Campaigns. In M. Maier, J. Strömbäck, \& L. L. Kaid (Eds.), Political communication in European parliamentary elections (pp. 161-174). Farnham, UK: Ashgate.

Tenscher, J. (2006). Low heated and half-hearted: The 2004 European Parliament campaign in its reception in Germany. In M. Maier \& J. Tenscher (Eds.), Campaigning in Europe-Campaigning for Europe. Political parties, campaigns, mass media and the European parliament elections 2004 (pp. 119-139). Berlin, Germany: LIT.

van Aelst, P., Sheafer, T., \& Stanyer, J. (2012). The personalization of mediated political communication: A review of concepts, operationalizations and key findings. Journalism, 13(2), 203-220. doi:10.1177/1464 884911427802

Vliegenthart, R. (2012). Analyzing comparative data: Opportunities and challenges. In F. Esser \& T. Hanitzsch (Eds.), ICA handbook series. Handbook of comparative communication research (pp. 486-497). New York: Routledge.

Vliegenthart, R., Boomgaarden, H. G., \& Boumans, J. W. (2011). Changes in political news coverage: Personalization, conflict and negativity in British and Dutch newspapers. In K. Brants \& K. Voltmer (Eds.), Political communication in postmodern democracy. Challenging the primacy of politics (pp. 92-110). Basingstoke: Palgrave Macmillan.

Vliegenthart, R., Schuck, A. R. T., Boomgaarden, H. G., \& de Vreese, C. H. (2008). News coverage and support for European integration, 1990-2006. International Journal of Public Opinion Research, 20(4), 415-439. doi:10.1093/ijpor/edn044

Voltmer, K., \& Eilders, C. (2003). The media agenda: The marginalization and domestification of Europe. In $\mathrm{K}$. H. Goetz \& K. Dyson (Eds.), Proceedings of the British academy: Vol. 119. Germany, Europe and the politics constraint (pp. 173-198). Oxford: Oxford University Press.

Weßels, B. (2005). Europawahlen, Wählermobilisierung und europäische Integration. In J. Tenscher (Ed.), Wahl-Kampf um Europa. Analysen aus Anlass der Wahlen zum Europäischen Parlament 2004 (pp. 86104). Wiesbaden, Germany: Springer VS.

Wilke, J., \& Reinemann, C. (2005). Zwischen Defiziten und Fortschritten. Die Berichterstattung deutscher Tageszeitungen zu den Europawahlen 1979-2004. In J. Tenscher (Ed.), Wahl-Kampf um Europa. Analysen aus Anlass der Wahlen zum Europäischen Parlament 2004 (pp. 157-176). Wiesbaden, Germany: Springer VS.

Wirth, W., \& Kolb, S. (2012). Securing equivalence: Problems and solutions. In F. Esser \& T. Hanitzsch (Eds.), ICA handbook series. Handbook of comparative communication research (pp. 469-485). New York: Routledge. 
Zeh, R., \& Schulz, W. (2015). Fernsehnachrichten über Kanzlerkandidaten. Die Trends seit 1990. In C. HoltzBacha (Ed.), Die Massenmedien im Wahlkampf. Die
Bundestagswahl 2013 (pp. 173-188). Wiesbaden, Germany: Springer VS.

\section{About the Author}

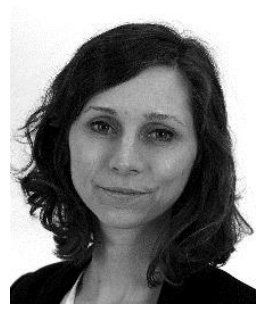

\section{Heidi Schulze}

Heidi Schulze is a research assistant and PhD candidate with the European Data Laboratory for Comparative Social Research (EUROLAB) at GESIS-Leibniz Institute for the Social Sciences in Cologne, Germany. Her research interests include political \& risk communication, public opinion, opinion-forming processes in online environments, and computational social sciences. 